\title{
Comparative Study of Magnetic, Electric and Botanical Seed Treatments on Seedling Characters of Tomato (Solanum lycopersicum L.)
}

\author{
R. Jane Priscy*, Prashant Kumar Rai, Saritha Khandka, \\ Bazil Avinash Singh and Basani Nihar
}

Department of Genetics and Plant Breeding, Naini Agricultural Institute, Sam Higginbottom University of Agriculture, Technology and Sciences, Prayagraj, 211007 U. P., India

*Corresponding author

\section{A B S T R A C T}

The experiment was conducted to standardize the best treatment of electromagnetic and botanicals for Tomato (PKM-1). Three methods of priming viz-

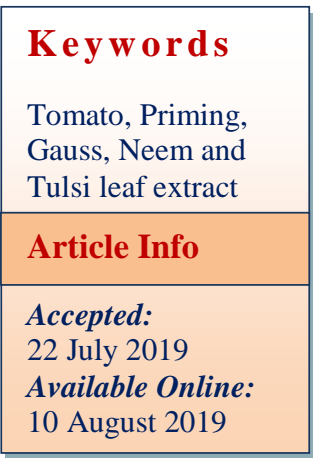
magnetopriming, electropriming, and organicpriming with control (Unprimed) were evaluated by screening different duration ( 15 minutes, 30 minutes, 6 hours and 12 hours) and different concentrations viz., $\mathrm{T}_{0}$-Unprimed (Control), magnetopriming - $\mathrm{T}_{1}-200$ gauss @ 15 minutes, $\mathrm{T}_{2}-200$ gauss @ 30 minutes, $\mathrm{T}_{3}-400$ gauss @15 minutes, $\mathrm{T}_{4}-400$ gauss @30 minutes, electro-priming- $\mathrm{T}_{5}-100 \mathrm{~mA} @ 15$ minutes, $\mathrm{T}_{6}-100 \mathrm{~mA} @ 30$ minutes, $\mathrm{T}_{7^{-}} 200 \mathrm{~mA} @ 15$ minutes, $\mathrm{T}_{8^{-}} 200 \mathrm{~mA} @ 30$ minutes, organic-priming- $\mathrm{T}_{9^{-}}$Neem Leaf Extract (10\%) @6 hours, $\mathrm{T}_{10^{-}}$Neem Leaf Extract (10\%) @ 12 hours, $\mathrm{T}_{11^{-}}$Tulsi Leaf Extract (10\%) @6 hours, $\mathrm{T}_{12^{-}}$ Tulsi Leaf Extract (10\%) @ 12 hours. The study revealed that the seed treatment with magneto-priming ( $\mathrm{T}_{4}-400$ gauss @ 30 minutes), ( $\mathrm{T}_{3}-400$ gauss @ 15 minutes) and organic-priming ( $\mathrm{T}_{10^{-}}$Neem leaf extract (10\%) @ 12 hours) recorded better performance in maximum seed quality parameters as compared to other treatments and control on the basis of lab studies.

\section{Introduction}

Tomato (Solanum lycopersicum L.) is an important vegetable crop and which has the chromosomal number of $2 n=24$.It is the annual herb and it is Self-pollinated crop. It has a significant role in human nutrition in human diet (Fekadu et al., 2004) and belonging to Solanaceae family, and to the order solanales. Its origin is the Andean zone particularly Peru-Ecuador-Bolivian areas but cultivated tomato originated in Mexico. The Spanish introduced the tomato into Europe in the early $16^{\text {th }}$ century and the mid- $16^{\text {th }}$ century tomatoes have been cultivated and consumed in southern Europe, though they only became wide spread in north-western Europe by the end of the $18^{\text {th }}$ century (Harvey et al., 2002).

It is widely employed in cannery and made into soups, conserves, pickles, ketchup, sauces, juices etc. Tomato juice has become 
an exceedingly popular appetizer and beverage. The well ripe tomato (per100g of edible portion) contains water (94.1\%), energy (23calories), calcium (1.0g), magnesium (7.0mg), vitamin A (1000IU), ascorbic acid $(22 \mathrm{mg})$, thiamin $(0.09 \mathrm{mg})$, riboflavin $(0.03 \mathrm{mg})$ and niacin (0.8mg) (Uddain et al., 2009).

Priming is water-based process, performed on seeds to increase germination uniformity \& thus enhances vegetable stand establishment. Seed priming is a low cost \& low risk invention, used to overcome poor stand establishment. The rationale of seed priming is to lessen the time between planting and emergence and to protect seeds from biotic and abiotic factors during critical phase of seedling establishment and to synchronize emergence, which leads to uniform stand as well as improved yield (Krishnaswami and Srimarthi, 2001). Priming is controlled hydration technique and enhances seed performance by increasing germination rate and uniformity resulting in faster and better seedling development in various crops (Powell et al., 2000, Afzal et al., 2011). Leaves of the plant contain alkaloids and phenolic compounds which protect the plants against pathogens and also produce antioxidant activity (Satish et al., 2007).

Magnetic and electromagnetic treatments are being used in agriculture, as a noninvasive technique, to improve the germination of seeds and increase crops and yields (Martmez et al., 2009). Researchers consider that the prospect of using cheap magnetic energy to improve the properties of soil and plant growth and development may be of great practical importance (Mohamed and Ebead, 2013). Magnetic field has been found to improve food reserve utilization and help for better absorption and assimilation of nutrients by plants (P. kavi, 1977) and photosynthetic activities (Lebedev et al., 1977). The choice of the investigated plants is based mainly on the importance they have. It has been found that the percent germination rates of the treated tomato seeds were accelerated about 1.1 to 2.8 times compared with that of the untreated seed, while an inhibitory effect on germination was shown in the case of the electric field more than $12 \mathrm{kV} / \mathrm{cm}$ and the exposure time more than 60 seconds (Moon and Chung, 2000).

So keeping these aspects in view the present experiment entitled Comparative study of magnetic, electric and botanical seed treatments on seedling characters of Tomato (Solanum lycopersicum L.) was carried out with following objectives:

To determine the effect of different presowing Seed treatment of magnetic field, electric field and botanicals on seedling characteristics and to identify the suitable Presowing Seed treatment of electric field, magnetic field and botanicals on seedling behaviour of tomato seeds.

\section{Materials and Methods}

The experiment was conducted in Post Graduate Laboratory, Department of Genetics and Plant Breeding, Sam Higginbottom University of Agriculture, Technology and Sciences, Prayagraj (U.P.) Tomato (PKM-1). In this experiment different (15 minutes, 30 minutes, 6 hours and 12 hours) duration on different concentrations viz., $\mathrm{T}_{0}$-Unprimed (Control), $\mathrm{T}_{1}$-200 gauss @ 15 minutes, $\mathrm{T}_{2}-200$ gauss @ 30 minutes, $\mathrm{T}_{3}-400$ gauss @ 15 minutes, $\mathrm{T}_{4}-400$ gauss @ 30 minutes, $\mathrm{T}_{5^{-}} 100$ mA @ 15 minutes, $\mathrm{T}_{6}-100 \mathrm{~mA} @ 30$ minutes, $\mathrm{T}_{7-} 200 \mathrm{~mA} @ 15$ minutes, $\mathrm{T}_{8^{-}} 200 \mathrm{~mA} @ 30$ minutes, $\mathrm{T}_{9-}$ Neem Leaf Extract (10\%)@6 hours, $\mathrm{T}_{10^{-}}$Neem Leaf Extract $(10 \%) @ 12$ hours, $\mathrm{T}_{11^{-}}$Tulsi Leaf Extract $(10 \%)$ @ 6 hours, $\mathrm{T}_{12^{-}}$Tulsi Leaf Extract (10\%) @ 12 hours were used. After cleaning and grading, the seeds of tomato were soaked in respective 
priming solutions at different volume of seeds for fifteen minutes, thirty minutes, six hours and twelve hours. Then the seeds were air dried under the shade to bring back to their original moisture content and used for sowing.

\section{Preparation of solution}

For the preparation of the Botanical solution (Tulsi and Neem leaf extract), 10 gram of each were taken in a beaker filled with $1000 \mathrm{ml}$. of distilled water accompanied by constant stirring. The volume of solution was then finally constituted to one liter and hence $1 \%$ stock solution of each chemical was prepared. The flasks containing chemicals were covered with muslin cloth to avoid any contamination.

\section{Magnetic Field}

An electromagnetic field generator "Testron EM-20" with variable static magnetic field (SMF) strength (50 to $500 \mathrm{mT}$ ) with a gap of 5 $\mathrm{cm}$ between pole pieces was fabricated. A D.C. power supply (80V/10A) with continuously variable output current was used for the electromagnet.

A digital gauss meter model DGM-30 operating on the principle of Hall Effect monitored the field strength produced in the pole gap. The probe is made of Indium Arsenide to crystal and was encapsulated to a non- magnetic sheet of $5 \mathrm{~mm} \times 4 \mathrm{~mm} \times 1 \mathrm{~mm}$ which was able to measure 0-2 Tesla with fullscale range in increments of 5 MT. By regulating the current in the coils, desired strength of SMF was monitored, which was measured by a Gauss meter. The strength and duration was standardized for maximum enhancement of germination and vigour of seeds.

The observation on the seedling characters viz., Germination percent, Root length $(\mathrm{cm})$, Shoot length $(\mathrm{cm})$, Seedling length $(\mathrm{cm})$,
Seedling Fresh weight (g), Seedling dry weight (g), Seedling Vigour index I, Seedling Vigour index II and electrical conductivity were recorded. The experimental data recorded were subjected to statistical analysis for calculating analysis of variance, range, mean, critical difference and coefficient of variation.

\section{Results and Discussions}

According to the results, all studied traits were affected by the treatments and there was completely significant difference between control (un-treated seed) and primed seeds (Table-1).

All seedling characters viz. Germination percent, Root length $(\mathrm{cm})$, Shoot length $(\mathrm{cm})$, Seedling length $(\mathrm{cm})$, seedling fresh weight (g), seedling dry weight (g), Seedling Vigour index-I, Seedling Vigour index-II and electrical conductivity were affected by $\mathrm{T}_{4}$ 400 gauss @ 30 minutes significantly recorded maximum values whereas lowest was observed in $\mathrm{T}_{0^{-}}$Control (un-treated seed) (Table- 2).

Significantly higher germination percent $(92.25 \%)$ reported in treatment $\mathrm{T}_{4}-400$ gauss @ 30 minutes followed by $\mathrm{T}_{3}-400$ gauss @ 15 minutes $(91.50 \%)$ and $\mathrm{T}_{10^{-}}$Neem leaf extract $(90.50 \%)$. Minimum germination percent was recorded in $\mathrm{T}_{0^{-}}$Control $(80.25 \%)$.

The maximum root length $(8.39 \mathrm{~cm})$ was recorded by $\mathrm{T}_{4}-400$ gauss @ 30 minutes followed by $\mathrm{T}_{3}-400$ gauss @ 15 minutes $(8.02$ $\mathrm{cm})$ and $\mathrm{T}_{10^{-}}$Neem Leaf Extract $(7.67 \mathrm{~cm})$. Minimum root length recorded in $\mathrm{T}_{0^{-}}$Control $(3.85 \mathrm{~cm})$.

The maximum shoot length $(12.15 \mathrm{~cm})$ recorded by $\mathrm{T}_{4}-400$ gauss @ 30 minutes followed by $\mathrm{T}_{3}-400$ gauss @ 15 minutes $(11.74 \mathrm{~cm})$ and $\mathrm{T}_{10^{-}}$Neem leaf extract $(11.24$ 
$\mathrm{cm})$. Minimum shoot length was founded in $\mathrm{T}_{0^{-}}$Control $(6.44 \mathrm{~cm})$.

The maximum seedling length $(20.54 \mathrm{~cm})$ was recorded in $\mathrm{T}_{4}-400$ gauss @ 30 minutes followed by $\mathrm{T}_{3}-400$ gauss @ 15 minutes $(19.76 \mathrm{~cm})$ and $\mathrm{T}_{10^{-}}$Neem leaf extract $(18.91$ $\mathrm{cm})$. Minimum seedling length was recorded in $\mathrm{T}_{0^{-}}$Control $(10.29 \mathrm{~cm})$. The maximum seedling fresh weight $(32.40 \mathrm{mg})$ was reported in $\mathrm{T}_{4}-400$ gauss @ 30 minutes followed by $\mathrm{T}_{3^{-}}$
400 gauss @ 15 minutes $(30.85 \mathrm{mg})$ and $\mathrm{T}_{10^{-}}$ Neem Leaf Extract (29.85 mg). Minimum seedling fresh weight was found in $\mathrm{T}_{0^{-}}$ Control (18.77 mg).

The maximum seedling dry weight $(10.72 \mathrm{mg})$ was recorded in $\mathrm{T}_{4}-400$ gauss @ 30 minutes followed by $\mathrm{T}_{3}-400$ gauss @ 15 minutes $(10.22 \mathrm{mg})$ and $\mathrm{T}_{10^{-}}$Neem leaf extract $(9.89$ $\mathrm{mg})$. Minimum seedling dry weight was found in $\mathrm{T}_{0^{-}}$Control $(6.21 \mathrm{mg})$.

Treatment Details

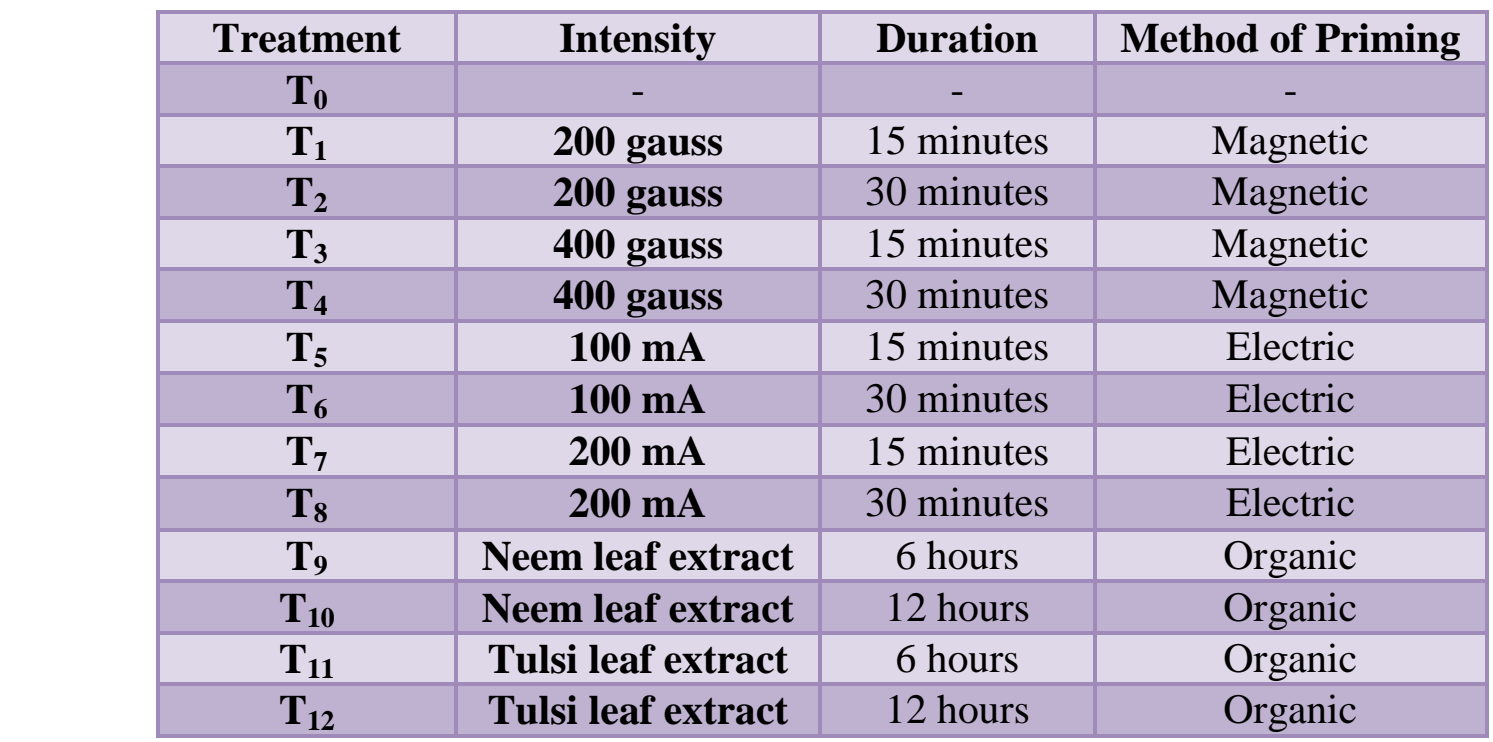

Legends: $\mathrm{T}=$ Treatment

$\mathrm{mA}=$ milli amperes

Table.1 Analysis of variance for 9 seedling characters in Tomato

\begin{tabular}{|c|c|c|c|}
\hline S. No. & Characters & \multicolumn{2}{|c|}{ Mean sum of squares } \\
\cline { 2 - 4 } & & Treatments $(\mathbf{d f}=\mathbf{1 2})$ & Error (df=39) \\
\hline $\mathbf{1 .}$ & Germination Percentage & $62.68^{* *}$ & 2.53 \\
\hline $\mathbf{2 .}$ & Root Length & $8.35^{* *}$ & 0.14 \\
\hline $\mathbf{3 .}$ & Shoot Length & $13.69^{* *}$ & 0.17 \\
\hline $\mathbf{4 .}$ & Seedling Length & $42.15^{* *}$ & 0.21 \\
\hline $\mathbf{5 .}$ & Seedling Fresh Weight & $72.33^{* *}$ & 0.12 \\
\hline $\mathbf{6 .}$ & Seedling Dry Weight & $7.84^{* *}$ & 0.01 \\
\hline $\mathbf{7 .}$ & Seedling Vigour Index I & $488809.56^{* *}$ & 3571.58 \\
\hline $\mathbf{8 .}$ & Seedling Vigour Index II & $95488.98^{* *}$ & 248.53 \\
\hline $\mathbf{9 .}$ & Electrical conductivity & $0.012^{* *}$ & 0.001 \\
\hline
\end{tabular}

** significant at $5 \%$ level of significance 
Table.2 Mean performance of tomato for 9 seedling characters

\begin{tabular}{|c|c|c|c|c|c|c|c|c|c|c|}
\hline $\begin{array}{l}\text { S. } \\
\text { No. }\end{array}$ & $\begin{array}{c}\text { Treatm } \\
\text { ents }\end{array}$ & $\begin{array}{c}\text { Germina } \\
\text { tion } \%\end{array}$ & $\begin{array}{c}\text { Root } \\
\text { Leng } \\
\text { th } \\
(\mathrm{cm})\end{array}$ & $\begin{array}{c}\text { Shoot } \\
\text { Lengt } \\
\text { h } \\
(\mathrm{cm})\end{array}$ & $\begin{array}{c}\text { Seedli } \\
\text { ng } \\
\text { Lengt } \\
\text { h } \\
(\mathrm{cm})\end{array}$ & $\begin{array}{c}\text { Seedlin } \\
\text { g Fresh } \\
\text { Weight } \\
\text { (gm) }\end{array}$ & $\begin{array}{c}\text { Seedlin } \\
\text { g Dry } \\
\text { Weight } \\
\text { (gm) }\end{array}$ & $\begin{array}{l}\text { Seedling } \\
\text { Vigour } \\
\text { Index I }\end{array}$ & $\begin{array}{c}\text { Seedlin } \\
\text { gVigou } \\
\text { r Index } \\
\quad \text { II }\end{array}$ & $\begin{array}{c}\text { Electri } \\
\text { cal } \\
\text { Condu } \\
\text { ctivity }\end{array}$ \\
\hline 1 & $\mathbf{T}_{\mathbf{0}}$ & 80.25 & 3.85 & 6.44 & 10.29 & 18.77 & 6.21 & 799.48 & 498.54 & 0.511 \\
\hline 2 & $\mathbf{T}_{1}$ & 85.50 & 5.90 & 8.81 & 14.71 & 24.58 & 8.11 & 1258.12 & 694.09 & 0.396 \\
\hline 3 & $\mathbf{T}_{2}$ & 86.75 & 6.28 & 9.29 & 15.57 & 25.70 & 8.50 & 1351.19 & 737.84 & 0.392 \\
\hline 4 & $\mathbf{T}_{\mathbf{3}}$ & 91.50 & 8.02 & 11.74 & 19.76 & 30.85 & 10.22 & 1808.97 & 935.62 & 0.321 \\
\hline 5 & $\mathbf{T}_{4}$ & 92.25 & 8.39 & 12.15 & 20.54 & 32.40 & 10.72 & 1896.01 & 989.19 & 0.318 \\
\hline 6 & $\mathbf{T}_{5}$ & 81.50 & 4.35 & 6.91 & 11.26 & 20.41 & 6.75 & 918.72 & 550.30 & 0.474 \\
\hline 7 & $\mathbf{T}_{6}$ & 82.25 & 4.71 & 7.39 & 12.10 & 21.27 & 7.04 & 994.91 & 579.05 & 0.464 \\
\hline 8 & $\mathbf{T}_{7}$ & 83.50 & 5.17 & 8.02 & 13.19 & 21.85 & 7.39 & 1102.05 & 617.21 & 0.420 \\
\hline 9 & $\mathbf{T}_{8}$ & 84.50 & 5.55 & 8.44 & 13.99 & 23.62 & 7.81 & 1181.81 & 660.32 & 0.413 \\
\hline 10 & $\mathbf{T}_{9}$ & 89.75 & 7.35 & 10.70 & 18.06 & 28.56 & 9.46 & 1621.21 & 849.28 & 0.371 \\
\hline 11 & $\mathbf{T}_{10}$ & 90.50 & 7.67 & 11.24 & 18.91 & 29.85 & 9.89 & 1712.06 & 895.10 & 0.368 \\
\hline 12 & $\mathbf{T}_{11}$ & 87.50 & 6.60 & 9.78 & 16.38 & 26.78 & 8.85 & 1433.60 & 774.84 & 0.380 \\
\hline 13 & $\mathrm{~T}_{12}$ & 89.00 & 6.95 & 10.25 & 17.20 & 27.55 & 9.12 & 1531.43 & 812.24 & 0.377 \\
\hline \multicolumn{2}{|c|}{ Grand Mean } & 86.51 & 6.21 & 9.32 & 15.53 & 25.55 & 8.47 & 1354.58 & 737.97 & 0.400 \\
\hline \multicolumn{2}{|c|}{ C.D. $(5 \%)$} & 2.27 & 0.53 & 0.59 & 0.66 & 0.51 & 0.15 & 85.47 & 22.56 & 0.050 \\
\hline \multicolumn{2}{|c|}{ SE(m) } & 0.79 & 0.18 & 0.20 & 0.23 & 0.17 & 0.05 & 29.88 & 7.88 & 0.017 \\
\hline \multicolumn{2}{|c|}{ C.V. } & 1.83 & 5.02 & 4.45 & 3.00 & 1.39 & 1.23 & 4.41 & 2.13 & 5.87 \\
\hline
\end{tabular}

The maximum seedling vigour index-I (1896.01) was recorded in $\mathrm{T}_{4}-400$ gauss @ 30 minutes followed by $\mathrm{T}_{3}-400$ gauss @ 15 minutes (1808.97) and $\mathrm{T}_{10^{-}}$Neem Leaf Extract (1712.06). Minimum seedling vigour index-I was recorded in $\mathrm{T}_{0^{-}}$Control (799.48).

The maximum seedling vigour index-II (989.19) was recorded in $\mathrm{T}_{4}-400$ gauss @ 30 minutes followed by $\mathrm{T}_{3}-400$ gauss @ 15 minutes (935.62) and $\mathrm{T}_{10^{-}}$Neem Leaf Extract (895.10). Minimum seedling vigour index-II was recorded in $\mathrm{T}_{0^{-}}$Control (498.54).

The minimum electrical conductivity (0.318) was recorded in $\mathrm{T}_{4}-400$ gauss @ 30 minutes followed by $\mathrm{T}_{3}-400$ gauss @ 15 minutes (0.321) and $\mathrm{T}_{10^{-}}$Neem leaf extract (0.368). Maximum electrical conductivity was recorded in $\mathrm{T}_{0^{-}}$Control (0.511).
Fresh weight were higher in plants treated with magnetic treatment. A. Abou et al., (2012). Pre-sowing treatment of corn seeds with pulsed EMFs 30 min improved plant fresh and dry weight. Seeds that have been exposed to MF for $30 \mathrm{~min}$ have been found to perform the best results with economic impact on producer's income in a context of a modern, organic, and sustainable agriculture (Bilalis et al., 2012).

The primed seeds showed higher seed vigour index-I better germination pattern and higher vigour level than non- primed (Aksyonov et al., 2001). Vashisth and Nagarajan (2010) revealed that vigor index (18-74\%) of sunflower were increased at different magnetic fields compared with control treatment. Pre-sowing treatment with magnetic field in wheat seeds resulted in 
higher germination and gluten content S. Pietruszewski, (1996). Moon and Chung, (2000) found that the percent germination rates of the tomato seed treated with $\mathrm{AC}$ electric and magnetic fields were accelerated about 1.1-2.8 times compared with that of the untreated seeds. Bondarenko et al., (1996) used a device for magnetic field treatment in field experiments in Russia and found that in vegetable seeds the germination percentage was higher and the plant growth in early stages was higher too.

The maximum vigour index-II with magnetic pre-soaking seed treatment might be due to cumulative effect of seedling dry weight and germination percentage which were greatly influenced by magnetic treatment in tomato seed at laboratory conditions. Similarly, the effect of magnetic field doses (strength and exposure time) tested in the present study are in agreement with those of other workers (Aladjadjiyan, 2002; Dagoberto et al., 2002; Harichand et al., 2002; Martinez et al., 2002, Moon \& Chung, 2002).

Increase in magnetic field gives lower EC values and all electrical field treatment gave higher EC values Kubisz L. (2012). The magnetic field is believed to influence the structures of cell membranes and in this way increases their permeability and ion transport through the ion channels, which then affects various metabolic activities Waleed et al., (2013).

It is concluded from the present investigation that the Pre-sowing treatment of magneticfield with $\mathrm{T}_{4}-400$ gauss @ 30 minutes showed maximum increase in germination ability and vigour and showed maximum increase in germination. Magnetic treatment to the tomato seeds for 15 minutes and 30 minutes, in which 400 gauss @ 30 minutes best result to enhanced germination ability, vigour and seedling characters. These conclusions are based on the results of six months investigation and therefore further investigation is needed to arrive at valid recommendations.

\section{Acknowledgement}

I gratefully record my indebtedness to all the faculty members of the Department of Genetics and Plant Breeding, SHUATS, for their constant encouragement and support.

\section{References}

Abou El-Yazied, A., A. M. El-Gizawy, S. M. Khalf, A. El-Satar, and O. A. Shalaby, (2012). "Effect of magnetic field treatments for seeds and irrigation water as well as $\mathrm{N}, \mathrm{P}$ and $\mathrm{K}$ levels on productivity of tomato plants," Journal of Applied Sciences Research, vol. 8, no. 4, pp. 2088-2099.

Afzal, I., S.M.A. Basra and N. Ahmad. (2011). Hormonal priming induces salt tolerance in wheat through enhanced antioxidant defence system. Cereal Research Communication, 39: 334- 337.

Aksyonov SI, Bulychev AA, Grunina T (2001). Effects of ELF-EMF treatment of wheat seeds at different stages of germination and possible mechanism of their origin. ElectromagBiol Med 20:231-253.

Aladjadjiyan, A. (2002).Study of the influence of magnetic field on some biological Characteristics of Zea mays. J. Central Eur. Agricu., 3: 89-94.

Anon, (1999). AOAC International qualitative and quantitiatve microbiology guidelines for methods validati0n.J. AOAC Int., 82, 402-16.

Baki A, Anderson JD. (1973).Vigor determination in Soybean seed by multiple criteria. Crop Sci. 13: 630-633.

Bilalis, D.J., Katsenios, N., Efthimiadou, A., and Karkanis, A. (2012). Pulsed electro-magnetic field: an organic compatible method to promote plant growth and yield in two corn types. Electromagn. Biol. Med. 31, 333343.doi: 10.3109/15368378.2012.661699

Bondarenko, N. F., E. E. Rokhinson, E. Z. Gak, and L. F. Klygina, (1996). "Magnetic 
equipment in agriculture," Russian AgriculturalSciences, vol. 2, pp. 30-34.

Dagoberto, G.F., D.S.T. Angel and S.P. Lilita. (2002). Effect of magnetic treatment of onion (Allium cepa) seeds on the germination and growth of seedlings. Alimentaria, 39: 181186.

Fisher, R.A. (1936). The correlation between relative on the supposition of genotypes grown in Kumaun Himalaya, Indian Journal Genetics. 66(1): 37-38.

Harichand, K.S., V. Narula, D. Raj and G. Singh. (2002). Effect of magnetic fields on germination, vigour and seed yield of wheat. Seed Res., 30: 289-293.

ISTA (2004). International Seed Testing Association (2004) International rules for seed testing. ISTA, Zürich: P. 206.

Kavi, P. S. (1977). "The effect ofmagnetic treatment of soybean seed on itsmoisture absorbing capacity," Science and Culture, vol. 43, pp. 405-406.

Krishnasamy, V. and P. Srimathi. (2001). Seed Management of rainfed agriculture. In: Land and use planning and watershed management in Rainfed Agriculture (ed.) Balusamy, M., C.R. Chinnamuthu and A. Velayutham. Centre of Advanced studies, Department of Agronomy, Tamilnadu Agricultural University, Coimbatore. Pp. 140.

Kubisz, L., (2012). Effect of low frequency magnetic field on germination of onion (Allium cepa L.) seeds. Actaphysicapolonica 19(3): 271-277.

Lebedev, I. S., L. G. Litvinenko, and L. T. Shiyan, (1977). "After effect of a permanent magnetic field on photochemical activity of chloroplasts," Soviet Plant Physiology, vol. 24, pp. 394-395. Int. Agrophys. 18, 65-71.

Martinez, E., M.V. Carbonell and M. Florez. (2002). Magnetic biostimulation of initial growth stages of wheat (Triticumaestivum, L.). Electromagnetic Biol. Med., 21: 43-53.

Mohamed, A. I. and B. M. Ebead, (2013). "Effect of irrigation with magnetically treated water on faba bean growth and composition," International Journal of Agricultural Policy and Research, vol. 1, no. 2, pp. 24-40.

Moon, J. D. and H. S. Chung, (2000). "Acceleration of germination of tomato seed by applying AC electric and magnetic fields," Journal of Electrostatics, vol. 48, no. 2, pp. 103-114.

Pietruszewski, S., (1996). "Effects of magnetic biostimulation of wheat seeds on germination, yield and proteins," International Agrophysics, vol. 10, no. 1, pp. 51-55.

Powell, A.A., L.J. Yule, H.C. Jingh, and S.P.C. Groot. (2000). The influence of aerated hydration seed treatment on seed longevity as assessed by the viability equation. Journal of Experimental Botany, 51: 2031-2043.

Presley, J. T. (1958). Relation of protoplast permeability to cotton seed viability and predisposition of seedling disease.Pl. Dis. Retr., 42, 852.

Satish, S., D.C. Mohana, M.P. Ranhavendra and K.A. Raveesha. (2007). Antifungal activity of some plant extracts against important seed borne pathogens of Aspergillussp. Journal of Agriculture Technology, 3: 109-119.

Vashisth A, Nagarajan S (2010). Effect on germination and early growth characteristics in sunflower (Helianthus annuus) seeds exposed to static magnetic field. J Plant Physiol 167:149-156.

Waleed AJ, riyadh CA, Hussein FH. (2013). Effect of magnetic field on seed germination of Triticumaestivum. World journal of agriculture science 5:168-171.

\section{How to cite this article:}

Jane Priscy R., Prashant Kumar Rai, Saritha Khandka, Bazil Avinash Singh and Basani Nihar. 2019. Comparative Study of Magnetic, Electric and Botanical Seed Treatments on Seedling Characters of Tomato (Solanum lycopersicum L.). Int.J.Curr.Microbiol.App.Sci. 8(08): 27852791. doi: https://doi.org/10.20546/ijcmas.2019.808.320 